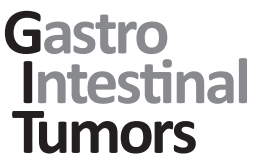

\title{
Rare Neoplasia of the Stomach
}

\author{
Christian Schulz Kerstin Schütte Peter Malfertheiner \\ Department of Gastroenterology, Hepatology and Infectious Diseases, Otto von Guericke \\ University Magdeburg, Magdeburg, Germany
}

\section{Key Words}

Gastric polyps - Gastrointestinal stromal tumor - Lymphoma of the stomach .

Neuroendocrine tumors · Secondary neoplasia

\begin{abstract}
Background: Gastric adenocarcinoma accounts for more than $90 \%$ of malignant lesions of the stomach. Besides this entity, numerous neoplastic lesions with malignant or benign characteristics as well as lesions with uncertain malignant potential occur. This review gives an overview on rare neoplasia of the stomach, focusing on gastric polyps, gastrointestinal stromal tumors, gastric lymphoma and neuroendocrine neoplasia. Summary: A broad spectrum of rare neoplastic lesions of the stomach with significant differences in malignant potential and with specific demands of interventional therapy is known. In addition to the use of highdefinition endoscopy techniques, the histopathological assessment of lesions and of the surrounding mucosa is mandatory to characterize and differentiate malignant and benign tumors. Key Message: Rare neoplasia of the stomach is detected in approximately $6 \%$ of patients undergoing esophagogastroduodenoscopy. Diligent examination of the gastric mucosa remains essential to detect mucosal and submucosal lesions. Practical Implications: Presenting with a broad spectrum of symptoms, ranging from unspecific abdominal discomfort to gastrointestinal bleeding or symptoms of gastric outlet obstruction, different rare neoplastic lesions of the stomach with demand of specific diagnostic and therapeutic work-up occur. Diligent endoscopic evaluation of the entire gastric mucosa, preferably by high-definition endoscopy techniques, is essential in addition to histopathological examination of lesional and surrounding tissue.

(C) 2015 S. Karger AG, Basel
\end{abstract}




\section{Introduction}

Although the definition of 'rare' varies throughout the world, with a prevalence of $<0.05 \%$ defining rare diseases in Europe [1], a threshold of $0.04 \%$ in Japan and of $0.075 \%$ in the United States [2], all gastric neoplasias, including gastric adenocarcinoma, fulfill this definition (table 1). Gastric adenocarcinoma is by far the most frequent malignant gastric tumor, accounting for $90 \%$ of malignant lesions, and is not considered in this review. All other malignant neoplastic entities together account for $<10 \%$ and present with a great variety. Apart from gastric adenocarcinoma, malignant and benign tumors as well as lesions with uncertain malignant potential occur. Diagnostic and therapeutic management differs highly depending on the nature of these tumors. Metastases from other primary tumors may occur as well and are discussed elsewhere.

This review will focus on gastric polyps, gastrointestinal stromal tumors (GISTs), lymphomas and neuroendocrine neoplasias.

\section{Gastric Polyps}

In approximately $6 \%$ of asymptomatic patients undergoing esophagogastroduodenoscopy in the United States gastric polyps are detected [3], whereas a study in China [4] reported gastric polyps in about $1 \%$ of individuals. The majority of gastric polyps are fundic gland polyps (77\%), followed by hyperplastic polyps (17\%), adenomas $(0.69 \%)$ and inflammatory fibroid polyps ( $0.1 \%$ ). Only $2 \%$ of gastric polyps are diagnosed as malignant neoplasia. Advanced endoscopic imaging allows to differentiate benign from malignant tumors by several characteristics, including the surface pit pattern as well as the macroscopic assessment of the lesion and the surrounding mucosa.

Hyperregenerative epithelium can result in the development of hyperplastic polyps. These conditions are observed in chronic inflammatory stimuli like Helicobacter pylori infection, adjacent mucosa to gastric ulcer or near gastroesophageal or gastrointestinal anastomoses. These polyps are usually detected incidentally and asymptomatic. In rare clinical settings, erosions of the surface can lead to gastrointestinal bleeding or symptoms of gastric outlet obstruction. Advanced endoscopy techniques allow the differentiation of hyperplastic polyps due to their typical surface (table 2) $[5,6]$. The risk of malignancy increases with the

Table 1. Gastric tumor entities

\begin{tabular}{ll}
\hline Epithelial tumors & Non-epithelial tumors \\
\hline Adenoma with intraepithelial neoplasia & Leiomyoma \\
Carcinoma & Schwannoma \\
Adenocarcinoma & Granular cell tumor \\
$\quad$ Intestinal type & Glomus tumor \\
$\quad$ Diffuse type & Leiomyosarcoma \\
Papillary adenocarcinoma & GIST \\
Tubular adenocarcinoma & Kaposi sarcoma \\
Mucinous adenocarcinoma & Malignant lymphomas \\
Signet-ring cell carcinoma & Marginal zone B-cell lymphoma of MALT type \\
Adenosquamous carcinoma & Mantle cell lymphoma \\
Squamous cell carcinoma & Diffuse large B-cell lymphoma \\
Undifferentiated carcinoma & Secondary tumors \\
Neuroendocrine neoplasms & \\
\hline
\end{tabular}



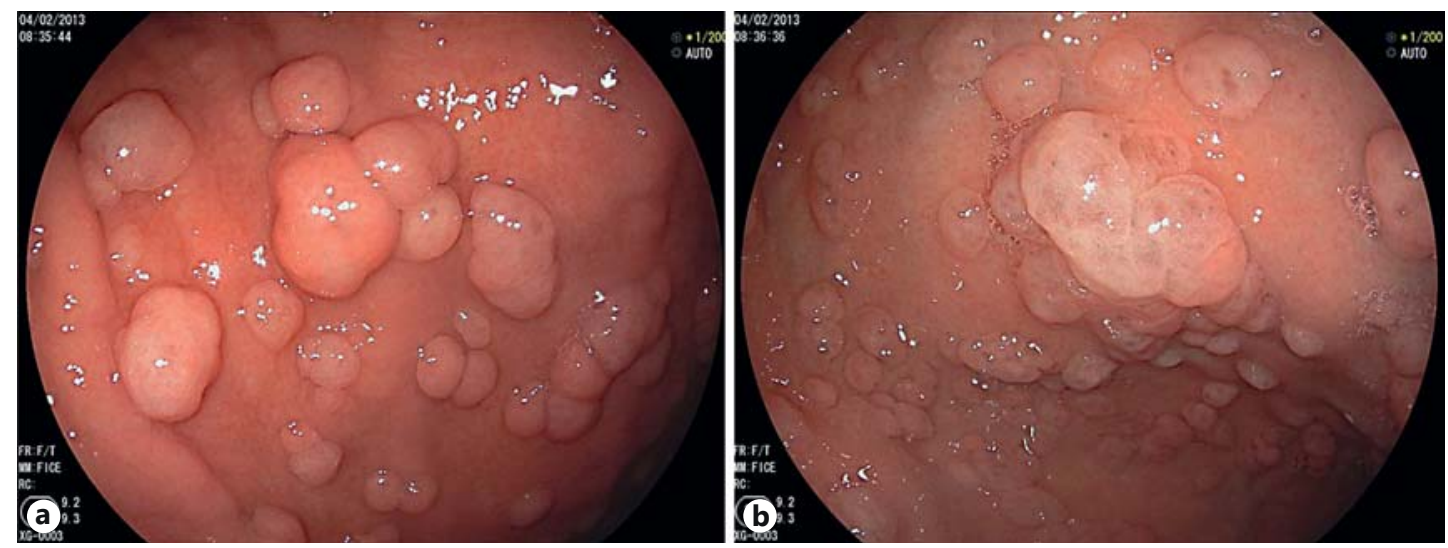

Fig. 1. a Fundic gland polyps. b Fundic gland polyps and adenoma.

Table 2. Endoscopic features of gastric polyps [5, 6, 36]

\begin{tabular}{|c|c|c|c|}
\hline & Hyperplastic polyps & Adenomas & $\begin{array}{l}\text { Fundic gland } \\
\text { polyps }\end{array}$ \\
\hline Macroscopy & $\begin{array}{l}\text { most frequently in the antrum, } \\
\text { often multiple, usually smooth, } \\
\text { dome-shaped, } 0.5-1.5 \mathrm{~cm} \text { in } \\
\text { diameter; large hyperplastic } \\
\text { polyps often become lobulated } \\
\text { and pedunculated, and the } \\
\text { surface epithelium is typically } \\
\text { eroded }\end{array}$ & $\begin{array}{l}\text { velvety lobulated appearance, } \\
\text { usually solitary; located more } \\
\text { often in the antrum }\end{array}$ & $\begin{array}{l}\text { multiple, small } \\
(<1 \mathrm{~cm}) \text {, appear } \\
\text { smooth, glassy, } \\
\text { and sessile }\end{array}$ \\
\hline $\begin{array}{l}\text { Confocal laser } \\
\text { endomicroscopy - } \\
\text { cytologic features }\end{array}$ & $\begin{array}{l}\text { regular columnar epithelium } \\
\text { cells covering gastric pits } \\
\text { identical to normal surface } \\
\text { columnar epithelium cells }\end{array}$ & $\begin{array}{l}\text { irregularly shaped black cells } \\
\text { encircled with white interstices } \\
\text { after intravenous fluorescein; } \\
\text { high gray-scale cells with } \\
\text { irregular size and enlarged } \\
\text { nuclei after topical acriflavine }\end{array}$ & \\
\hline $\begin{array}{l}\text { Confocal laser } \\
\text { endomicroscopy - } \\
\text { crypt architecture }\end{array}$ & $\begin{array}{l}\text { hyperplastic columnar } \\
\text { epithelium cells regularly } \\
\text { arranged and encircling the } \\
\text { openings of dilated, elongated } \\
\text { or branch-like pits (sulci) }\end{array}$ & $\begin{array}{l}\text { irregular ridges or villi } \\
\text { resembling cerebriform shape; } \\
\text { focal asymmetric ridge } \\
\text { distortion after topical } \\
\text { acriflavine; distorted or } \\
\text { ridge-like openings of glands }\end{array}$ & \\
\hline $\begin{array}{l}\text { Narrow-band } \\
\text { imaging features }\end{array}$ & $\begin{array}{l}\text { honeycomb and dense } \\
\text { vascular patterns }\end{array}$ & $\begin{array}{l}\text { the narrow-band imaging } \\
\text { features of gastric adenomas } \\
\text { are not yet well defined }\end{array}$ & $\begin{array}{l}\text { honeycomb } \\
\text { appearance with } \\
\text { dense vasculature }\end{array}$ \\
\hline
\end{tabular}

size of these polyps. Polyps $>1 \mathrm{~cm}$ as well as pedunculated polyps carry a higher risk. The diagnostic assessment should include gastric biopsies from the surrounding mucosa with respect to the Sydney classification. H. pylori should be eradicated. Hyperplastic polyps exceeding a size of $0.5 \mathrm{~cm}$ should be resected, preferably during endoscopy, allowing for histopathological examination of the resected tissue $[7,8]$. 


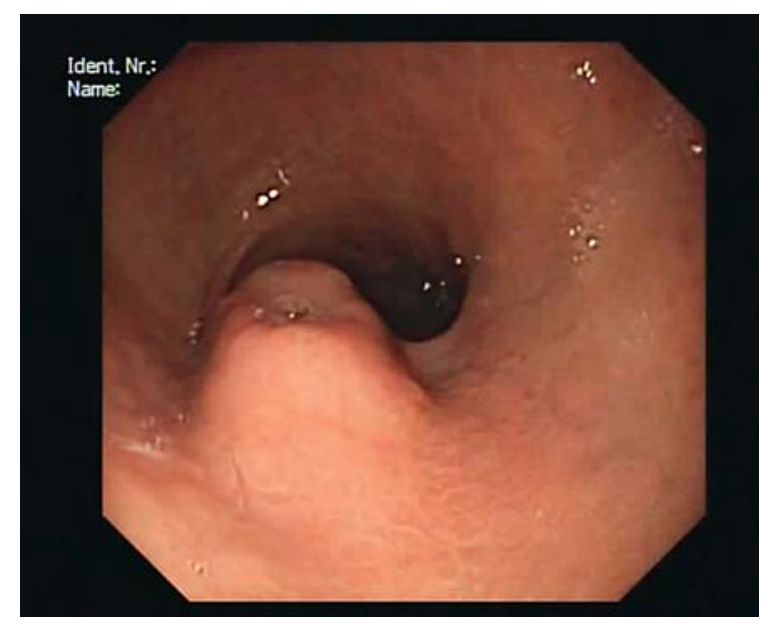

Fundic gland polyps (fig. 1) are the most common polyps and frequently occur in association with long-term proton pump inhibitor therapy (four-fold increase) or gastrinoma. The majority of these neoplasias are sporadic, whereas a minority occurs in patients with familial adenomatous polyposis, with polyposis syndromes, with MUTYH-associated polyposis and with gastric adenocarcinoma and proximal polyposis of the stomach. While sporadic fundic gland polyps and fundic gland polyps in association with long-term proton pump inhibitor therapy are without risk, somatic APC mutations are detectable in $>70 \%$ of fundic gland polyps associated with polyposis syndromes. Patients with $>20$ fundic gland polyps, young onset of the polyps ( $<40$ years), additional duodenal adenomas and fundic gland polyps in other regions than the gastric corpus are under suspicion for familial adenomatous polyposis. A colonoscopy is recommended in these patients. Furthermore, few case reports of fundic gland polyposis with gastric adenocarcinoma have been published [9].

Gastric adenoma is the most frequent neoplastic lesion of the stomach. These neoplasias occur mostly isolated and located in the distal stomach and are less frequently associated with familial adenomatous polyposis than fundic gland polyps. 8-59\% of gastric adenomas are associated with gastric cancer, therefore the entire stomach has to be examined diligently. Due to their malignant potential, all gastric adenomas should undergo endoscopic resection and follow-up [7].

\section{Gastrointestinal Stromal Tumors}

Mesenchymal tumors typically present as subepithelial neoplasms. GISTs are the most prevalent entity (fig. 2). Other significantly less frequent gastric mesenchymal tumors are leiomyoma, leiomyosarcoma and schwannoma. Histologically, GISTs are characterized by spindle cell, epithelioid or rarely pleomorphic tumors arising from the interstitial cells of Cajal or their precursors. In the majority of these cases they are driven by mutations in KIT and/or PDGFRA receptor tyrosine kinases. Less common oncogenic driver mutations include NF1, BRAF and succinate dehydrogenase mutations [10]. The classification of GISTs evolved significantly during the past decades. The diagnosis is based on conventional pathology together with immunohistochemical staining of characteristic marker proteins. c-KIT (CD117) is constitutionally expressed in 95\% of all GISTs. DOG1 is useful in the diagnosis of KIT-negative GISTs [10]. Less specific antigens are CD34 and nestin. Due to the changes in the diagnostic pathways, the prevalence of GISTs decreased by exclusion of many neoplasias formerly considered to be 
Table 3. Features of gastric NETs according to [20]

\begin{tabular}{llll}
\hline Feature & Type 1 & Type 2 & Type 3 \\
\hline $\begin{array}{l}\text { Proportion among gastric } \\
\text { neuroendocrine neoplasms }\end{array}$ & $70-80 \%$ & $5-6 \%$ & $14-25 \%$ \\
\hline Macroscopic aspect & $\begin{array}{l}\text { often small }(<1-2 \mathrm{~cm}), \\
78 \% \text { polypoid, 65\% } \\
\text { multiple }\end{array}$ & $\begin{array}{l}\text { often small }(<1-2 \mathrm{~cm}), \\
\text { polypoid and multiple }\end{array}$ & $\begin{array}{l}\text { unique, large }(>2 \mathrm{~cm}), \\
\text { polypoid, ulcerated }\end{array}$ \\
\hline $\begin{array}{l}\text { Pathological differentiation } \\
\text { often NET G1 }\end{array}$ & NET G1-G2 & NEC G3 \\
\hline Associated conditions & chronic atrophic gastritis & gastrinoma/MEN-1 & none \\
\hline
\end{tabular}

GISTs. In the Surveillance, Epidemiology, and End Results database of the National Cancer Institute of the United States, GISTs are responsible for $2.2 \%$ of malignant gastric tumors without any gender preference (male:female 1.1:1). The predilected age groups are in the 6th to 8th decade. $60-70 \%$ of GISTs are located in the stomach, followed by the midgut (20-30\%) and the esophagus and lower gastrointestinal tract (10\%) [11-13].

GISTs become clinically apparent with a broad spectrum of symptoms, ranging from unspecific abdominal discomfort to gastrointestinal bleeding or symptoms caused by distant metastases.

GISTs form a continuum in their biological behavior. Tumor size and mitotic activity (expressed per 50 high-power fields) are the pillars of prognostic assessment [14, 15]. In case of curative resection, the malignant potential of the tumor strongly influences the decision on adjuvant treatment. In advanced disease, systemic treatment with tyrosine kinase inhibitors is the standard of care, with imatinib being the standard in first-line treatment. Four different regions of KIT and three different regions of PDGFRA have been found to be mutated in sporadic GISTs. The location of the mutations strongly impacts on the response to systemic therapy with tyrosine kinase inhibitors [16]. Exon 9 KIT mutant GISTs are less sensitive to imatinib than exon 11 KIT mutant tumors, and tumors with exon 18 mutation in PDGFRA are resistant to imatinib. The analysis of the mutational status is therefore part of the routine work-up in GISTs requiring systemic therapy.

\section{Neuroendocrine Tumors of the Stomach}

The incidence of neuroendocrine tumors (NETs) is constantly rising [17, 18]. Gastric NETs show an additional increase in proportional incidence compared to all NETs of the gastroenteropancreatic system, accounting now for about $6-23 \%$ of gastrointestinal NETs [19]. It is not clear whether this is a consequence of rising numbers of esophagogastroduodenoscopies performed with increasing awareness of these lesions or a true incidence effect.

Although the majority of gastric NETs have a benign course and asymptomatic behavior, a subgroup has the potential to become aggressive and mimic the clinical course of gastric adenocarcinoma [20]. In general, all NETs have malignant potential. In the stomach, three distinct types of neuroendocrine neoplasms are distinguished from each other (table 3).

Type 1 gastric NETs constitute $70-80 \%$ of gastric NETs. They are often $<2 \mathrm{~cm}$, polypoid in the majority of cases and multiple in $65 \%$ of cases. They develop on the background of chronic atrophic gastritis, either due to autoimmune gastritis or as a consequence of $H$. pylori 

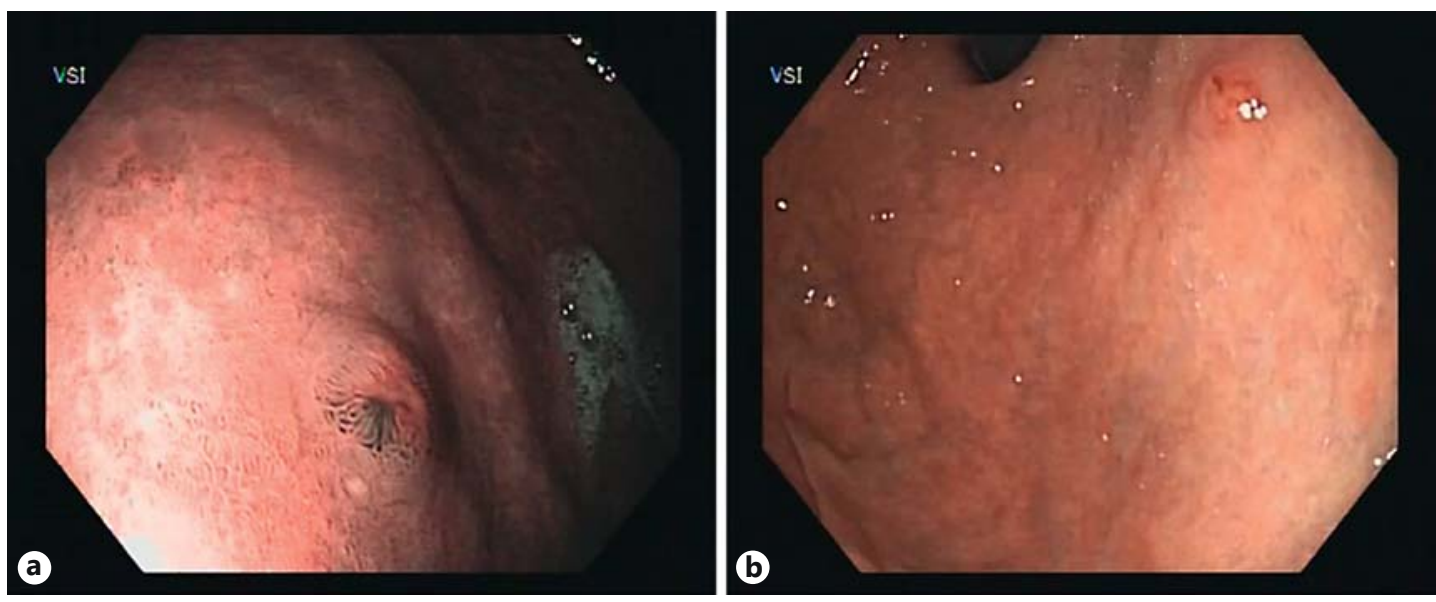

Fig. 3. a, b NET in chronic atrophic gastritis.

infection, and are predominantly found in the gastric corpus or fundus. Atrophy of the fundic glands leads to hypochlorhydria and hypergastrinemia, resulting in hyperplasia of enterochromaffin-like cells $[21,22]$. Female patients are more frequently affected than male patients. These gastric NETs are usually asymptomatic except for anemia, well-differentiated (G1) and show benign behavior with excellent survival rates, although a small proportion of patients develop distant metastases [23].

Type 2 gastric NETs are associated with hypergastrinemia as a consequence of ZollingerEllison syndrome, almost exclusively within the MEN-1 syndrome, and account for 5-6\% of gastric NETs. Endoscopically, they present as small, frequently multiple and polypoid lesions located mainly in the gastric fundus [20] (fig. 3). Distant metastases can be found in 10-30\% of cases.

Type 3 gastric NETs are not related to any chronic gastric pathology and occur as sporadic tumors. Macroscopically they present as unique, large $(>2 \mathrm{~cm})$, polypoid and ulcerated lesions [20]. The majority of them is poorly differentiated (G3). Male patients $>50$ years are predominantly affected. These tumors frequently are symptomatic, causing pain and/or weight loss $[20,24]$. More than half of the patients with these type 3 gastric NETs present with distant metastases, resulting in a rate of $25-30 \%$ of tumor-related deaths [24].

The WHO classification discriminates four subtypes of gastric NETs, with a distinct category for poorly differentiated high-grade malignant NETs [24, 25].

Advances in endoscopic imaging with high-resolution magnification endoscopy (NBI, FICE, BLI) have improved the endoscopic diagnosis of these tumors [21]. Staging including computed tomography or magnetic resonance imaging and somatostatin receptor scintigraphy are recommended in patients with type 3 gastric NETs.

A laboratory work-up including gastrin and chromogranin A level in the serum is recommended for all patients with gastric NETs in addition to characterization of underlying chronic gastric disease. Genetic analysis is recommended in case of suspected MEN-1.

In type 1 and 2 gastric NETs, upper gastrointestinal endoscopy is the only imaging procedure recommended for staging purposes. In polyps $>1 \mathrm{~cm}$ in size, endoscopic ultrasound may be used to rule out invasion of the depth of the gastric wall.

Recommendations for the management of gastric NETs have changed during the last decades. While initially the European Neuroendocrine Tumor Society (ENETS) guidelines recommended solely endoscopic surveillance for small type 1 NETs, endoscopic resection of these lesions in addition to endoscopic follow-up is now the preferred treatment of choice 

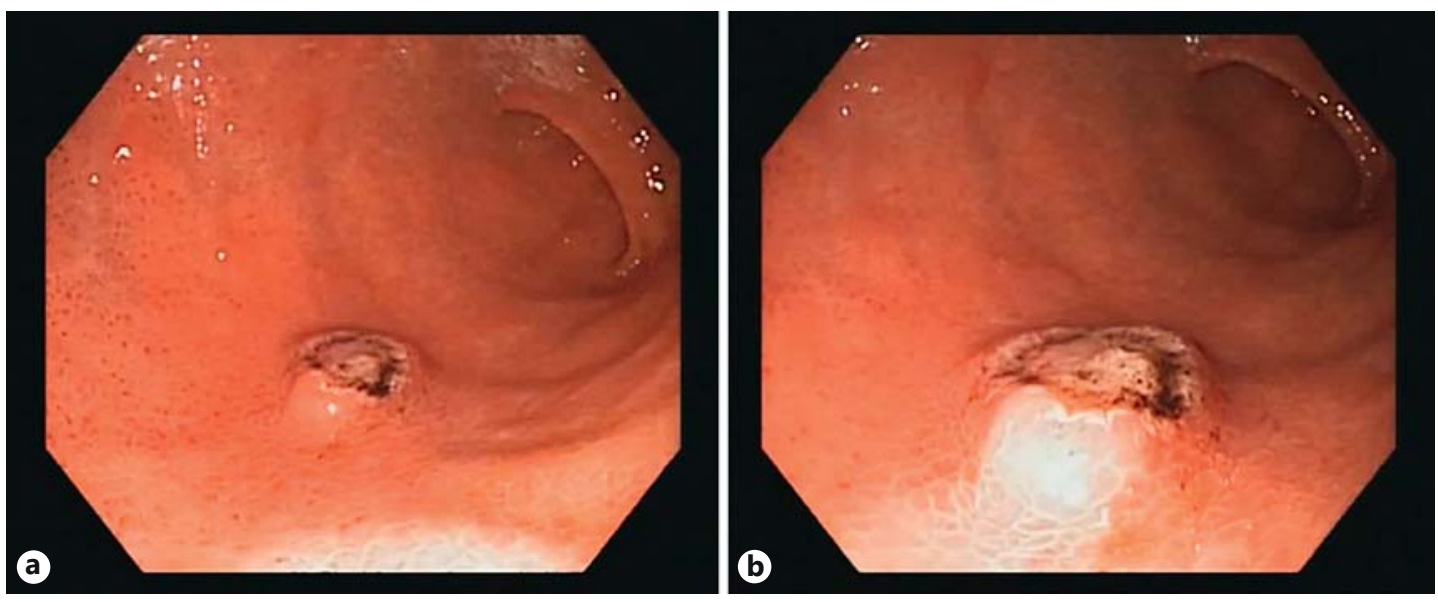

Fig. 4. a, b MALT lymphoma.

[20]. As type 1 NETs usually recur and progress to neuroendocrine carcinoma in about $3 \%$ of cases [26], endoscopic follow-up is mandatory. In case of submucosal involvement, incomplete endoscopic resection or metastases in lymph nodes or distant organs, a surgical approach is the treatment of choice [20]. Type 2 gastric NETs should be treated by local excision with yearly endoscopic follow-up, while the surgical approach in type 3 NETs should be similar to the treatment of gastric adenocarcinoma.

Patients with advanced and progressive disease should be treated with antiproliferative therapy. Somatostatin analogues and peptide receptor nucleotide therapy are options in G1 and G2 tumors, while patients with G3 neuroendocrine carcinoma should be treated with chemotherapy, applying a combination of cisplatin and etoposide. For detailed recommendations regarding the management of gastric NETs, the current ENETS guidelines [20] should be referred to.

\section{Lymphoma of the Stomach}

Primary lymphoma of the stomach is defined to either originate from the gastric wall or from the adjacent lymph nodes (fig. 4). More than $40 \%$ of non-Hodgkin lymphomas arise from extranodal locations, and the gastrointestinal tract is one of the most common extranodal sites. The prevalence of primary lymphoma of the gastrointestinal tract ranges from 4 to $18 \%$ in the Western world and is about $25 \%$ in the Middle East $[27,28]$. While the stomach is the most frequent site of origin in the Western world, the midgut is predominantly involved in the Middle East. The average age of onset is in the 5 th decade without any gender differences.

$H$. pylori infection is the leading cause of gastric mucosa-associated lymphoid tissue (MALT) lymphoma, accounting for about $90 \%$ of cases $[29,30]$. B-cell-associated antigens such as CD19, CD20, CD22 and sIg are frequently positive in immunohistochemical staining, whereas CD5, CD10, CD38 and IgD are negative [31].

Acquired or congenital immunosuppressive conditions are risk factors for lymphoma as well. Up to $23 \%$ of lymphomas arising from the gastrointestinal tract are described in HIVpositive patients. B-cell MALT lymphomas are the only low-grade lymphomas of the stomach, whereas the majority of gastric lymphomas belong to the high-grade B-cell lymphomas.

Symptoms are frequently unspecific, with abdominal discomfort and nausea, vomiting or signs of bleeding. Large lesions may be palpable in the epigastrium in advanced situations. 
The therapeutic approach depends on histopathological classification and staging according to the Ann Arbor classification. Early-stage MALT lymphoma regresses in most cases after $H$. pylori eradication therapy [32]. Lymphomas with genetic alterations [t $(11: 18)$ (q21:q21)] are at risk for eradication failure and the development of diffuse large B-cell lymphoma [33]. Advanced MALT lymphoma should be treated by radiotherapy with curative intention, and mantle cell lymphoma, diffuse large B-cell lymphoma or rare Burkitt lymphoma are treated by systemic chemotherapy in accordance with the stage of disease. Surgical therapy is indicated in case of complications such as bleeding or perforation.

\section{Secondary Neoplasia of the Stomach}

Metastases in the stomach from tumors of other origin are rare. Autopsy studies in cancer patients revealed a prevalence of gastric metastases in a range of $1.28-1.7 \%$. Most frequently gastric metastases originate from breast cancer, followed by melanoma and lung cancer. Other primary cancer entities are even more rare. Neither are preferential locations described nor are specific symptoms to be expected $[34,35]$.

\section{Summary}

There is a broad spectrum of rare neoplastic lesions of the stomach, with significant differences in malignant potential and with specific demands on interventional therapy. High-definition endoscopy techniques permit to differentiate between malignant and benign tumors. This has great impact on the initial endoscopic management of these tumors, either with biopsy or with endoscopic resection, but the histopathological assessment of lesions and the surrounding mucosa remains essential for treatment.

\section{Disclosure Statement}

All authors have no personal interests to disclose. Declaration of funding interests: none.

\section{References}

1 European Commission: Rare diseases. http://ec.europa.eu/health/rare_diseases/policy/index_en.htm.

2 National Institutes of Health: Diseases. https://rarediseases.info.nih.gov/gard/browse-by-first-letter.

-3 Carmack SW, Genta RM, Schuler CM, Saboorian MH: The current spectrum of gastric polyps: a 1-year national study of over 120,000 patients. Am J Gastroenterol 2009;104:1524-1532.

4 Cao H, Wang B, Zhang Z, Zhang H, Qu R: Distribution trends of gastric polyps: an endoscopy database analysis of 24,121 northern Chinese patients. J Gastroenterol Hepatol 2012;27:1175-1180.

-5 Shaib YH, Rugge M, Graham DY, Genta RM: Management of gastric polyps: an endoscopy-based approach. Clin Gastroenterol Hepatol 2013;11:1374-1384.

6 Li W, Zuo X, Zuo F, Gu X, Yu T, Zhao Y, Zhang T, Zhang J, Li Y: Characterization and identification of gastric hyperplastic polyps and adenomas by confocal laser endomicroscopy. Surg Endosc 2010;24:517-524.

-7 Hirota WK, Zuckerman MJ, Adler DG, Davila RE, Egan J, Leighton JA, Qureshi WA, Rajan E, Fanelli R, WheelerHarbaugh J, Baron TH, Faigel DO; Standards of Practice Committee, American Society for Gastrointestinal Endoscopy: ASGE guideline: the role of endoscopy in the surveillance of premalignant conditions of the upper GI tract. Gastrointest Endosc 2006;63:570-580.

-8 Sharaf RN, Shergill AK, Odze RD, Krinsky ML, Fukami N, Jain R, Appalaneni V, Anderson MA, Ben-Menachem T, Chandrasekhara V, Chathadi K, Decker GA, Early D, Evans JA, Fanelli RD, Fisher DA, Fisher LR, Foley KQ, Hwang JH, Jue TL, Ikenberry SO, Khan KM, Lightdale J, Malpas PM, Maple JT, Pasha S, Saltzman J, Dominitz JA, Cash BD: Endoscopic mucosal tissue sampling. Gastrointest Endosc 2013;78:216-224. 
-9 Yanaru-Fujisawa R, Nakamura S, Moriyama T, Esaki M, Tsuchigame T, Gushima M, Hirahashi M, Nagai E, Matsumoto T, Kitazono T: Familial fundic gland polyposis with gastric cancer. Gut 2012;61:1103-1104

-10 Rubin BP, Heinrich MC: Genotyping and immunohistochemistry of gastrointestinal stromal tumors: an update. Semin Diagn Pathol 2015, Epub ahead of print.

11 Tran T, Davila JA, El-Serag HB: The epidemiology of malignant gastrointestinal stromal tumors: an analysis of 1,458 cases from 1992 to 2000. Am J Gastroenterol 2005;100:162-168.

12 DeMatteo RP, Lewis JJ, Leung D, Mudan SS, Woodruff JM, Brennan MF: Two hundred gastrointestinal stromal tumors: recurrence patterns and prognostic factors for survival. Ann Surg 2000;231:51-58.

13 Emory TS, Sobin LH, Lukes L, Lee DH, O'Leary TJ: Prognosis of gastrointestinal smooth-muscle (stromal) tumors: dependence on anatomic site. Am J Surg Pathol 1999;23:82-87.

14 Miettinen M, Sobin LH, Lasota J: Gastrointestinal stromal tumors of the stomach: a clinicopathologic, immunohistochemical, and molecular genetic study of 1,765 cases with long-term follow-up. Am J Surg Pathol 2005; 29:52-68.

15 Miettinen M, Makhlouf H, Sobin LH, Lasota J: Gastrointestinal stromal tumors of the jejunum and ileum: a clinicopathologic, immunohistochemical, and molecular genetic study of 906 cases before imatinib with longterm follow-up. Am J Surg Pathol 2006;30:477-489.

16 Miettinen M, Lasota J: Gastrointestinal stromal tumors: review on morphology, molecular pathology, prognosis, and differential diagnosis. Arch Pathol Lab Med 2006;130:1466-1478.

17 Modlin IM, Oberg K, Chung DC, Jensen RT, de Herder WW, Thakker RV, Caplin M, Delle Fave G, Kaltsas GA, Krenning EP, Moss SF, Nilsson O, Rindi G, Salazar R, Ruszniewski P, Sundin A: Gastroenteropancreatic neuroendocrine tumours. Lancet Oncol 2008;9:61-72.

-18 Yao JC, Hassan M, Phan A, Dagohoy C, Leary C, Mares JE, Abdalla EK, Fleming JB, Vauthey JN, Rashid A, Evans DB: One hundred years after 'carcinoid': epidemiology of and prognostic factors for neuroendocrine tumors in 35,825 cases in the United States. J Clin Oncol 2008;26:3063-3072.

19 Niederle MB, Hackl M, Kaserer K, Niederle B: Gastroenteropancreatic neuroendocrine tumours: the current incidence and staging based on the WHO and European Neuroendocrine Tumour Society classification: an analysis based on prospectively collected parameters. Endocr Relat Cancer 2010;17:909-918.

20 Delle Fave G, Kwekkeboom DJ, van Cutsem E, Rindi G, Kos-Kudla B, Knigge U, Sasano H, Tomassetti P, Salazar R, Ruszniewski P: ENETS Consensus Guidelines for the management of patients with gastroduodenal neoplasms. Neuroendocrinology 2012;95:74-87.

21 Sato Y: Endoscopic diagnosis and management of type I neuroendocrine tumors. World J Gastrointest Endosc 2015;7:346-353.

22 Basuroy R, Srirajaskanthan R, Prachalias A, Quaglia A, Ramage JK: Review article: the investigation and management of gastric neuroendocrine tumours. Aliment Pharmacol Ther 2014;39:1071-1084.

-23 La Rosa S, Inzani F, Vanoli A, Klersy C, Dainese L, Rindi G, Capella C, Bordi C, Solcia E: Histologic characterization and improved prognostic evaluation of 209 gastric neuroendocrine neoplasms. Hum Pathol 2011;42: 1373-1384.

24 Ruszniewski P, Delle Fave G, Cadiot G, Komminoth P, Chung D, Kos-Kudla B, Kianmanesh R, Hochhauser D, Arnold R, Ahlman H, Pauwels S, Kwekkeboom DJ, Rindi G: Well-differentiated gastric tumors/carcinomas. Neuroendocrinology 2006;84:158-164.

25 Klöppel G, Scherübl H: Neuroendokrine Tumoren des Magens. Risikostratifizierung und Therapie. Pathologe 2010;31:182-187.

26 Bordi C: Gastric carcinoids. Ital J Gastroenterol Hepatol 1999;31(suppl 2):S94-S97.

27 Otter R, Bieger R, Kluin PM, Hermans J, Willemze R: Primary gastrointestinal non-Hodgkin's lymphoma in a population-based registry. Br J Cancer 1989;60:745-750.

28 Freeman C, Berg JW, Cutler SJ: Occurrence and prognosis of extranodal lymphomas. Cancer 1972;29:252-260. Eidt S, Stolte M, Fischer R: Helicobacter pylori gastritis and primary gastric non-Hodgkin's lymphomas. J Clin Pathol 1994;47:436-439.

-30 Wotherspoon AC, Ortiz-Hidalgo C, Falzon MR, Isaacson PG: Helicobacter pylori-associated gastritis and primary B-cell gastric lymphoma. Lancet 1991;338:1175-1176.

-31 Wotherspoon AC, Doglioni C, Diss TC, Pan L, Moschini A, de Boni M, Isaacson PG: Regression of primary lowgrade B-cell gastric lymphoma of mucosa-associated lymphoid tissue type after eradication of Helicobacter pylori. Lancet 1993;342:575-577.

-32 Malfertheiner P, Megraud F, O’Morain CA, Atherton J, Axon AT, Bazzoli F, Gensini GF, Gisbert JP, Graham DY, Rokkas T, El-Omar EM, Kuipers EJ; European Helicobacter Study Group: Management of Helicobacter pylori infection - the Maastricht IV/Florence Consensus Report. Gut 2012;61:646-664.

-33 Liu H, Ruskon-Fourmestraux A, Lavergne-Slove A, Ye H, Molina T, Bouhnik Y, Hamoudi RA, Diss TC, Dogan A, Megraud F, Rambaud JC, Du MQ, Isaacson PG: Resistance of $\mathrm{t}(11 ; 18)$ positive gastric mucosa-associated lymphoid tissue lymphoma to Helicobacter pylori eradication therapy. Lancet 2001;357:39-40.

34 Menuck LS, Amberg JR: Metastatic disease involving the stomach. Am J Dig Dis 1975;20:903-913.

-35 Berge T, Lundberg S: Cancer in Malmö 1958-1969. An autopsy study. Acta Pathol Microbiol Scand Suppl 1977; 260:1-235.

-36 Omori T, Kamiya Y, Tahara T, Shibata T, Nakamura M, Yonemura J, Okubo M, Yoshioka D, Ishizuka T, Maruyama N, Kamano T, Fujita H, Nakagawa Y, Nagasaka M, Iwata M, Arisawa T, Hirata I: Correlation between magnifying narrow band imaging and histopathology in gastric protruding/or polypoid lesions: a pilot feasibility trial. BMC Gastroenterol 2012;12:17. 